\title{
Heavy metals uptake ability from water by the Himalayan alder growing in Riparian habitat of Sino Japanese regions in Pakistan
}

Zahoor ul Haq ${ }^{1}$, Shujaul Mulk Khan ${ }^{1 *}$, Abdullah ${ }^{1}$, Asadullah ${ }^{2}$, Abdul Razzaq $^{3}$, Fazal Manan ${ }^{1}$, Saqib Kamran ${ }^{1}$, Sana Rasheed ${ }^{1}$ and Zeeshan Ahmad $^{1}$

1. Department of Plant Sciences, Quaid-i-Azam University Islamabad-Pakistan

2. Center of Plant biodiversity, University of Peshawar-Pakistan

3. Department of Botany, Islamia College University Peshawar-Pakistan

*Corresponding author's email: shuja60@gmail.com

Citation

Zahoor ul Haq, Shujaul Mulk Khan, Abdullah, Asadullah, Abdul Razzaq, Fazal Manan, Saqib Kamran, Sana Rasheed and Zeeshan Ahmad. Heavy metals uptake ability from water by the Himalayan alder growing in Riparian habitat of Sino Japanese regions in Pakistan. Pure and Applied Biology. Vol. 9, Issue 1, pp704-713. http://dx.doi.org/10.19045/bspab.2020.90076

\begin{tabular}{llll}
\hline \hline Received: 03/09/2019 & Revised: 01/12/2019 & Accepted: 12/12/2019 & Online First: 24/12/2019 \\
\hline \hline
\end{tabular}

\section{Abstract}

The excess amount of heavy metal in soil pose a serious risk for the life and food chain of living beings. The recommended and feasible procedure to combat heavy metal is plantation of trees with excellent capacity of accumulation. Alnus nitida is a plant species grown on the banks of rivers and streams in western Himalayas and Hindu Kush region of the Sino-Japanese belt. It plays a significant role in accumulation of heavy metals from water. In current study it was explored in the west from Bajaur to Kashmir in the east. For heavy metals analysis shoot, leaves Root and Bark of Alnus nitida were washed thoroughly under tap water and then placed in an $81{ }^{\circ} \mathrm{C}$ oven to dry it for about 5 minutes. After acid digestion plant material were put in falcon tube to raise the level of sample to $40 \mathrm{ml}$ through distilled water. The accumulation of heavy metal in Himalayan alder was assessed via atomic absorption spectroscopy. The Heavy Metals analyses were carried out to find the bioaccumulation ability of Alder by using standard formulas of bio concentration factor (BCF), Translocation Factor (TF) and Biological Accumulation Coefficient (BAC). It was observed an efficient accumulator of all the heavy metals as revealed by the values of BCF in shoots, $\mathrm{BCF}$ in roots and also the TF. Himalayan Alder has greatly declined through out in its habitat as a result of drought, developmental projects, deforestation and other anthropogenic activities. Current study can provide a baseline for further comprehensive studies heavy metals studies of other such species.

Keywords: Heavy metals; Himalayan alder; Pakistan; Sino Japanese regions

\section{Introduction}

Over the recent past decades Heavy metals sources have been increased due to rapid industrialization and use of inorganic materials in domestic as well as at industry level. From biological point of view the metalloids and metals can be harmful both for animals and plants at low concentration [1]. Heavy metals are of two types essential and non-essential. Non-essential metals don't play role in physiological functions i.e. $\mathrm{Pb}, \mathrm{Hg}, \mathrm{Se}, \mathrm{As}$ and Cd. Essential elements are required for 
metabolism i.e. $\mathrm{Cu}, \mathrm{Ni}, \mathrm{Zn}, \mathrm{Mo}, \mathrm{Co}$ and $\mathrm{Fe}$ [2]. Environmental pollution due to heavy metals led to an alarming situation due to disturbance of biogeochemical cycles and rapid industrialization [3]. Both anthropogenic and natural activities add heavy metals in environment. Natural sources are soil Erosion, weathering of valuable minerals and volcanos. The anthropogenic activities are Mining, smelting, use of pesticides etc [4]. Different herbs, Shrubs and Trees are used to eliminate heavy metals from the environment. All the plants show potential capability to reduce the amount to a range of least or eliminate it [5]. Tree species with phytofiltration are unable to grow in polluted area, for that reason different ecotypes of same species are grown in heavy metals rich area [6]. Plant species with mycorrhizal affiliation may reduce the risk of heavy metals on plant physiology as it resists the harmful effect of metals and enhance the growth of species. Himalayan alder is a special tree having mycorrhizal association and with excellent heavy metals accumulation capability. The alder tree absorb heavy metals and reduce the risk to its physiological or anatomical features by unique association with fungi [7-9]. Heavy metals accumulation studies on Alder species were carried out in different countries. As compare to Salix and Acer Alnus glutinosa was the plant species with greater survival rate planted in a highly alkaline anthropogenic sediment [10]. The Alnus nitida heavy metal studied were carried out first time from Pakistan in the present research work. The genus Alnus is distributed in various temperate regions of the world. According to [11] about 40 of its species distributed in Bhutan, China, Bangladesh, Europe, India, Korea, Japan, Nepal and America and Northern Hemisphere. Alnus are separated from each other by unique characters of nitrogen fixation [12].

The present research work is based on Alnus nitida a native plant of northern areas of Pakistan playing great rule not only economically as well as medicinally for the local inhabitants of the area. Many species in different areas of the world by are under consideration for test of accumulation of heavy metals. The present research work will provide a base for future researchers to consider different heavy metal accumulator plants to recommend species best for water purification.

\section{Materials and methods}

\section{Site description}

Research area is located in Sino-Japanese belt occurring in Himalayan-Hidukush territory of Pakistan. Survey was extended for heavy metals analysis thought out the area of Bajaur, Dir, Swat, Buner, Haripur and Kashmir. In the above mentioned selected zones few areas were analyzed for heavy metals analysis including Muzzafarabad (Kashmir), Nokhara, Pandh, Afreen tang, Rahat kot, Kokarai (Swat) Gokand (Buner) Ghor, Chianrkot, Manyal (Dir) (Fig.1)

\section{Sample collection}

At each sampling area Alnus nitida vigorous and healthy tree was selected to collect samples for analysis. All the plant samples were collected in samples, taking selected portion of root, leaf and bark and packed it in plastic bags in sampling area and brought to the laboratory as soon as possible to analyze it. The field visit and collection of samples was carried out in September 2017.

\section{Heavy metals analysis}

The shoot, leaves Root and Bark of Alnus nitida were washed thoroughly under tap water (roots were scrubbed with a brush carefully) and then placed in an $81{ }^{\circ} \mathrm{C}$ oven (company Walls) to be dried for about 5 minutes.

Plant metal uptake was determined by wet acid digestion [13]. The 0-.5 g dried plant material was grinded manually. Then $10 \mathrm{ml}$ NitricPerchloric acid (HNO3-HClO4) mixture (3:1 ratio) was supplemented to plant material in conical flask, and left it for overnight. After the initial digestion, the flasks having the material were then transferred to fume hood, and temperature was raised to $700 \mathrm{C}$ for 60 minutes. Temperature was steadily raised until the brown fumes turned into white fumes. Mixture was then permitted to cool for a few minutes, and diluted carefully with distilled water. Extract was filtered via filter paper (Whatmann No. 42) and $50 \mathrm{ml}$ volume was raised using 
distilled water. Filtered samples were then used to determine the concentrations of desired metal i.e. $\mathrm{Ni}, \mathrm{Cu}, \mathrm{Mn}, \mathrm{Co}, \mathrm{Zn}, \mathrm{Cd}, \mathrm{Cr}, \mathrm{Pb}, \mathrm{Mg}$, $\mathrm{Ca}, \mathrm{Na}, \mathrm{K}$ by flame atomic absorption spectrometry (Varian FAAS-240, Triad Scientific, New Jersy, USA) [14].

Formulae used for the analysis

Calculation of bioaccumulation coefficients (BAC), bio concentration factor (BCF) and translocation factor (TF)

The bioaccumulation factor and bioconcentration factor provide an index of the ability of the shoots and roots to accumulate the metal with respect to the metal concentration in the soil. (Malik et al. 2010). Biological Concentration Factor (BCF) was calculated as metal concentration ratio of plant roots to soil given in equation 2 [15]. Translocation Factor (TF) was described as ratio of heavy metals in plant shoot to that in plant root given in equation 2 [16]. Biological Accumulation Coefficient (BAC) was calculated as ratio of heavy metal in shoots to that in soil given in equation 1 [17].

$$
\mathrm{BAC}=\frac{\text { Metal Concentration in shoot }(\mathrm{mg} / \mathrm{kg})}{\text { Metal Concentration in soil }(\mathrm{mg} / \mathrm{kg})}
$$

$\mathrm{BCF}=\underline{\text { Metal concentration in roots }(\mathrm{mg} / \mathrm{kg})}$

Metal concentration in soil $(\mathrm{mg} / \mathrm{kg})$

The translocation factor was calculated according Ahmad et al. (2015)

$$
\mathrm{TF}=\frac{\text { Metal concentration in shoot }}{\text { Metal concentration in roots }(\mathrm{mg} / \mathrm{kg})}
$$

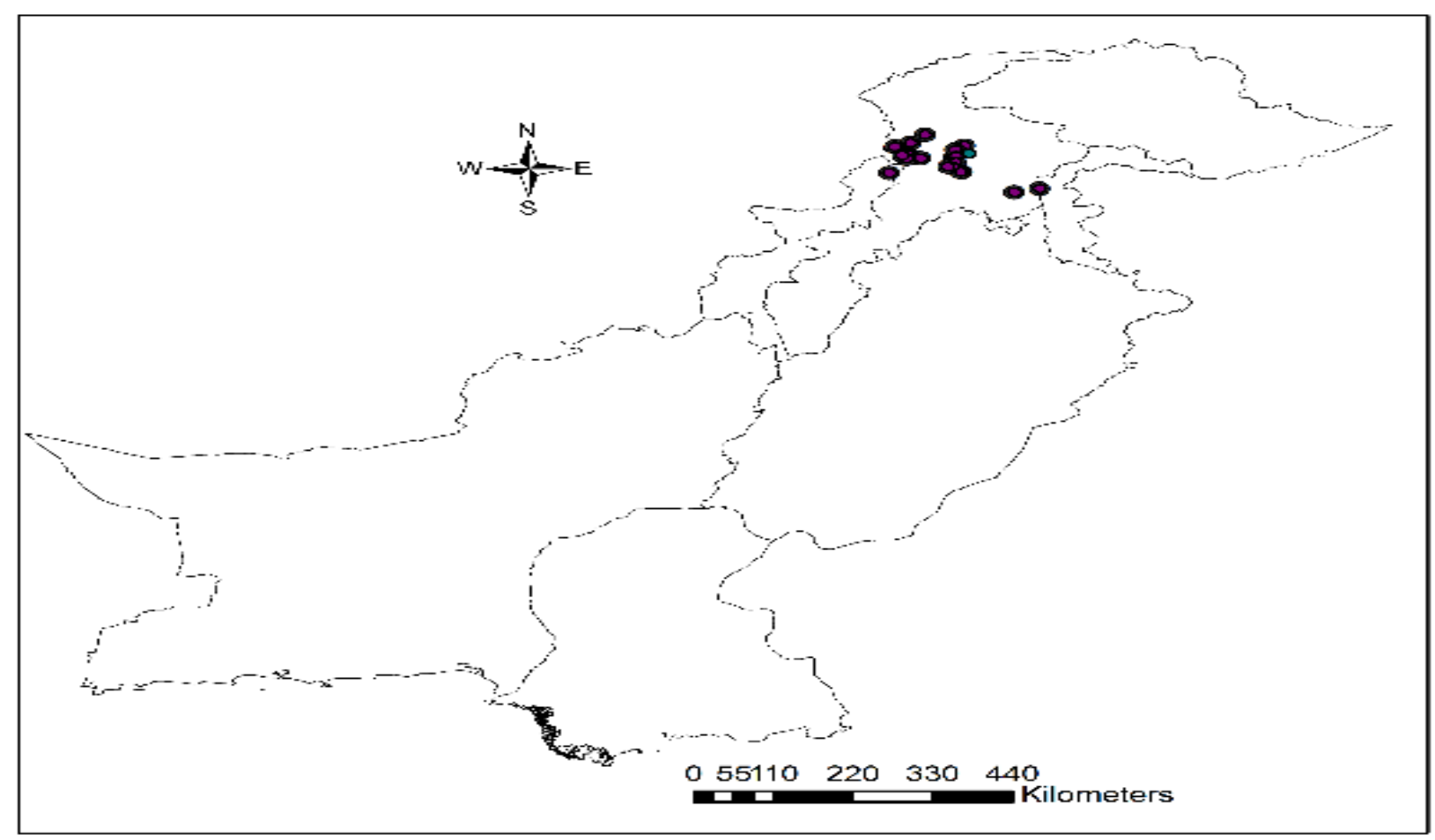

Fig. 1. Localities in Pakistan from which Alnus nitida specimen were collected 


\section{Results and discussion}

The Heavy metals uptake was examined in various parts of Himalayan Alder. The accumulation of metals in different part were previously observed by other scientists as [1820]. The [21] recorded excellent accumulation of metals in roots of the Alnus nepalensis. In present study Himalayan alder was collected from different region of western Himalayas to find the accumulation of metals. The localities were started from Kashmir in the east to Bajaur in the west. Six localities were targeted to find the accumulation of 12 heavy metals. The main reason for the presence of heavy metals in the area were industries, hotels, Domestic effluents and Construction work. The local people are facing many health issues while acquiring orally from them regarding the water quality. The disease of kidneys, cancer and digestive problems are common in the area. Different heavy metals absorbing plant especially planation of Alnus nitida will help to reduce the pollutants from the environment. After collection and analysis of samples it was noticed that $\mathrm{Ni}$ is present in all of them however its amount varies in water, soil and plant parts and also according to the site of collection (Table 1). In water samples highest $\mathrm{Ni}$ contamination is present in sample collected from Chinarkot $(404.5 \mu / \mathrm{L})$ followed by Ghor $(401.5 \mu / \mathrm{L})$. Highest $\mathrm{Ni}$ contaminated soil was observed in Muzaffarabad $(323.4 \mu / \mathrm{g})$ while lowest contaminated is in Gokand $(164.65 \mu / \mathrm{g})$. Average values of $\mathrm{Ni}$ contents in various samples revealed that plant showed efficient uptake of $\mathrm{Ni}$ and translocate it in different plant tissues. Highest $\mathrm{Ni}$ accumulation was observed in shoot (241.27) followed by root (202.77) (Fig. 2).The order of $\mathrm{Ni}$ accumulation in plant parts was in order as followed shoot>root>bark>leaves. $\mathrm{Cu}$ is present in all of them however its amount varies in soil and plant parts and also according to the site of collection (Table 1). In water samples highest $\mathrm{Cu}$ contamination is present in sample collected from Rahat Kot $(105.2 \mu / \mathrm{L})$ followed by Afreen tang $(27.45$ $\mu / \mathrm{L}$ ). (Fig. 3) Highest $\mathrm{Cu}$ contaminated soil was observed in Rahat Kot $(184.9 \mu / \mathrm{g})$ while lowest contaminated is in Manyal $(18.45 \mu / \mathrm{g})$. Average values of $\mathrm{Cu}$ contents in various samples revealed that plant showed efficient uptake of $\mathrm{Cu}$ and translocate it in different plant tissues. (Fig. 4) Highest $\mathrm{Cu}$ accumulation was observed in leaves (78.9) followed by (72.1). The order of $\mathrm{Cu}$ accumulation in plant parts was in order as followed Soil >root>water>leaves (Fig. 4) Mn is present in all of them however its amount varies in soil and plant parts and also according to the site of collection (Table $1 \&$ Fig. 4). In root samples highest $\mathrm{Mn}$ contamination is present in sample collected from Afreen tang $(269.1 \mu / \mathrm{L})$ followed by Gokand $(216.15 \mu / \mathrm{L})$. Highest $\mathrm{Mn}$ contaminated soil was observed in Muzaffarabad $(536.8 \mu / g)$ while lowest contaminated is in Muzzafarabad $(8.7 \mu / \mathrm{g})$. Average values of $\mathrm{Mn}$ contents in various samples revealed that plant showed efficient uptake of $\mathrm{Mn}$ and translocate it in different plant tissues. Highest $\mathrm{Ni}$ accumulation was observed in stem (321.27) followed by root $(18 \mathrm{u} / \mathrm{g})$. The order of $\mathrm{Mn}$ accumulation in plant parts was in order as followed soil> Roots $>$ stem >leaves. (Fig. 5) $\mathrm{Zn}$ is present in all of them however its amount varies in water, soil and plant parts and also according to the site of collection (Table 1) (Fig. 6). In root samples highest $\mathrm{Zn}$ contamination is present in sample collected from Afreen tang (324.45 $\mu / \mathrm{L})$ followed by Gokand (319.15 $\mu / \mathrm{L})$. Highest $\mathrm{Zn}$ contaminated soil was observed in Afreen tang $(345.6 \mu / g)$ while lowest contaminated is in Chinarkoy $(40 \mu / \mathrm{g})$. $\mathrm{Cr}$ is present in all of them however its amount varies in water, soil and plant parts and also according to the site of collection (Table 1) (Fig. 7). In root samples highest $\mathrm{Cr}$ contamination is present in sample collected from Pandh $(2194.1 \mu / \mathrm{L})$ followed by Nokhara $(77.65 \mu / \mathrm{L}) . \mathrm{Pb}$ is present in all of them however its amount varies in water, soil and plant parts and also according to the site of collection (Table $1 \&$ Fig. 7). In root samples highest $\mathrm{Pb}$ contamination is present in sample collected from Rahat kot $(321.9 \mu / \mathrm{L})$ followed by Gokand $(131.85 \mu / \mathrm{L})$. Mg is present in all of 
them however its amount varies in water, soil and plant parts and also according to the site of collection (Table $1 \&$ Fig. 8). In root samples highest $\mathrm{Mg}$ contamination is present in sample collected from Rahat kot $(841 \mu / \mathrm{L})$ followed by Manyal $(142.2 \mu / \mathrm{L})$. Ca is present in all of them however its amount varies in water, soil and plant parts and also according to the site of collection (Table $1 \&$ Fig. 9). In root samples highest $\mathrm{Ca}$ contamination is present in sample collected from Nokhara $(2363.18 \mu / \mathrm{L})$ followed by Pandh $(2100 \mu / \mathrm{L})$. (Fig. 10) $\mathrm{Na}$ is present in all of them however its amount varies in water, soil and plant parts and also according to the site of collection (Table $1 \&$ Fig. 11). In root samples highest $\mathrm{Na}$ contamination is present in sample collected from Rahat kot $(6614.1 \mu / \mathrm{L})$ followed by Muzzafarabad $(3786.6 \mu / \mathrm{L})$. $\mathrm{K}$ is present in all of them however its amount varies in water, soil and plant parts and also according to the site of collection (Table $1 \&$ Fig. 12). In root samples highest $\mathrm{K}$ contamination is present in sample collected from Rahat kot $(163.075$ $\mu / \mathrm{L})$ followed by Muzzafarabad $(187.75 \mu / \mathrm{L})$. Plant was observed an efficient accumulator of $\mathrm{Ni}$ as revealed by the values $(>1)$ of $\mathrm{BCF}$ in shoots, BCF in roots and also the TF (Fig. $2 \&$ Fig. 13). From current sampling and research it is revealed that plants growing at localities Alnus showed highest Phyto-extraction of heavy metals. Reason behind is the presence of increased heavy metals contents in soil sample as compared to others [21, 22]. Plant was observed an efficient accumulator as revealed by the values $(>1)$ of $\mathrm{BCF}$ in Stem, BCF in roots and also the TF.

Table 1. BAC, BCF and TF values of Alnus nitida in different stations

\begin{tabular}{|c|c|c|c|c|c|c|c|c|c|c|}
\hline $\mathrm{Cu}$ & & GK-Buner & SK-Hazara & GR-Dir & MN-Dir & KK-Swat & $\begin{array}{c}\text { AT- } \\
\text { Swat }\end{array}$ & $\begin{array}{c}\text { PD- } \\
\text { Swat }\end{array}$ & NK-Swat & MZ-Kashmir \\
\hline & BAC & 0.071102 & 9.55 & 0.113302 & 2.148649 & 2.442049 & 0.996078 & 0.813688 & 1.419009 & 15.15517 \\
\hline & $\mathrm{BCF}$ & 0.54986 & 0.686695 & 0.097167 & 1.621622 & 0.9941 & 7.035294 & 0.711027 & 0.698795 & 15.15517 \\
\hline & $\mathrm{TF}$ & 1.896071 & 1.029181 & 1.697674 & 1.326304 & 1.080956 & 1.68107 & 0.976165 & 1.103953 & 1 \\
\hline \multirow[t]{3}{*}{$\mathrm{Mg}$} & $\mathrm{BAC}$ & 0.531401 & 1.079341 & 0.35957 & 0.888889 & 0.829312 & 1.31746 & 1.230337 & 0.646259 & 0.549451 \\
\hline & $\mathrm{BCF}$ & 0.769928 & 0.848802 & 0.117376 & 2.943089 & 1 & 5.190476 & 0.893258 & 1.14966 & 0.549451 \\
\hline & $\mathrm{TF}$ & 0.690196 & 1.271605 & 3.063399 & 0.302026 & 0.829312 & 0.253823 & 1.377358 & 0.56213 & 1 \\
\hline \multirow[t]{3}{*}{$\mathrm{Mn}$} & BAC & 0.071102 & 9.2103 & 0.113302 & 2.148649 & 2.442049 & 0.996078 & 0.813688 & 1.419009 & 15.15517 \\
\hline & $\mathrm{BCF}$ & 0.54986 & 0.686695 & 0.097167 & 1.621622 & 0.978437 & 7.035294 & 0.711027 & 0.698795 & 15.15517 \\
\hline & $\mathrm{TF}$ & 0.129308 & 13.4125 & 1.166052 & 1.325 & 2.495868 & 0.141583 & 1.144385 & 2.030651 & 1 \\
\hline \multirow[t]{3}{*}{$\mathrm{Zn}$} & $\mathrm{BAC}$ & 0.173032 & 0.470022 & 0.386948 & 0.138697 & 0.08895 & 0.25307 & 0.018147 & 25.68236 & 2.015042 \\
\hline & $\mathrm{BCF}$ & 0.132697 & 0.013323 & 0.171359 & 1.081747 & 0.99863 & 3.763598 & 0.45642 & 4.073446 & 2.015042 \\
\hline & $\mathrm{TF}$ & 1.303965 & 35.27778 & 2.258112 & 0.128215 & 0.089072 & 0.067241 & 0.039759 & 6.304824 & 1 \\
\hline \multirow[t]{3}{*}{$\mathrm{Cd}$} & $\mathrm{BAC}$ & 1.40625 & 0.757174 & 0.986152 & 0.991736 & 1.030367 & 1.061053 & 1.011379 & 1.108494 & 1.027778 \\
\hline & $\mathrm{BCF}$ & 1.221774 & 1.002208 & 0.887755 & 1.010331 & 1.012712 & 1.031579 & 0.967871 & 1.017131 & 1.027778 \\
\hline & $\mathrm{TF}$ & 1.15099 & 0.755507 & 1.110837 & 0.981595 & 1.017434 & 1.028571 & 1.044952 & 1.089825 & 1 \\
\hline \multirow[t]{3}{*}{$\mathrm{Cr}$} & BAC & 0.18886 & 6.256173 & 4.0666667 & 1.281834 & 1.246442 & 1.043284 & 1.282967 & 0.876334 & 1.086691 \\
\hline & $\mathrm{BCF}$ & 0.692611 & 0.601852 & 27 & 0.794567 & 0.985157 & 2.897015 & 1.288462 & 0.888889 & 0.818681 \\
\hline & $\mathrm{TF}$ & 0.272678 & 10.39487 & 0.150617 & 1.613248 & 1.265222 & 0.360124 & 0.995736 & 0.985876 & 1.327368 \\
\hline \multirow[t]{3}{*}{$\mathrm{Pb}$} & BAC & 1.698113 & 1.096774 & 1.714286 & 1.371841 & 0.81203 & 1.194444 & 0.965278 & 1.019608 & 1.515152 \\
\hline & $\mathrm{BCF}$ & 0.849057 & 1.225806 & 1 & 1.299639 & 1.150376 & 2.633333 & 0.833333 & 0.921569 & 0.681818 \\
\hline & $\mathrm{TF}$ & 2 & 0.894737 & 1.714286 & 1.055556 & 0.705882 & 0.453586 & 1.158333 & 1.106383 & 2.222222 \\
\hline $\mathrm{Ca}$ & BAC & 8.940901 & 2.509368 & 0.849654 & 5.712463 & 0.410692 & 0.371798 & 1.203061 & 0.210161 & 0.215341 \\
\hline
\end{tabular}


Haq et al.

\begin{tabular}{|c|c|c|c|c|c|c|c|c|c|c|}
\hline & BCF & 8.496972 & 3.335102 & 0.57031 & 1.734884 & 0.999811 & 0.074926 & 0.49326 & 0.78763 & 2.76882 \\
\hline & TF & 1.052246 & 0.752411 & 1.489812 & 3.292706 & 0.41077 & 4.962209 & 2.438997 & 0.266827 & 1.2 \\
\hline Na & BAC & 5.834167 & 1.881074 & 0.482173 & 3.302683 & 0.603242 & 1.18058 & 1.114004 & 0.256454 & 0.780767 \\
\hline & BCF & 4.944279 & 2.945158 & 0.783043 & 2.233437 & 1.009646 & 0.677456 & 0.608898 & 0.585664 & 0.882769 \\
\hline & TF & 1.179983 & 0.6387 & 0.615768 & 1.478745 & 0.597479 & 1.742667 & 1.829542 & 0.437885 & 1 \\
\hline K & BAC & 5.834167 & 1.881074 & 0.482173 & 3.302683 & 0.603242 & 1.18058 & 1.114004 & 0.256454 & 0.780767 \\
\hline & BCF & 4.944279 & 2.945158 & 0.783043 & 2.233437 & 1.009646 & 0.677456 & 0.608898 & 0.585664 & 0.882769 \\
\hline & TF & 1.179983 & 0.6387 & 0.615768 & 1.478745 & 0.597479 & 1.742667 & 1.829542 & 0.437885 & 1 \\
\hline
\end{tabular}

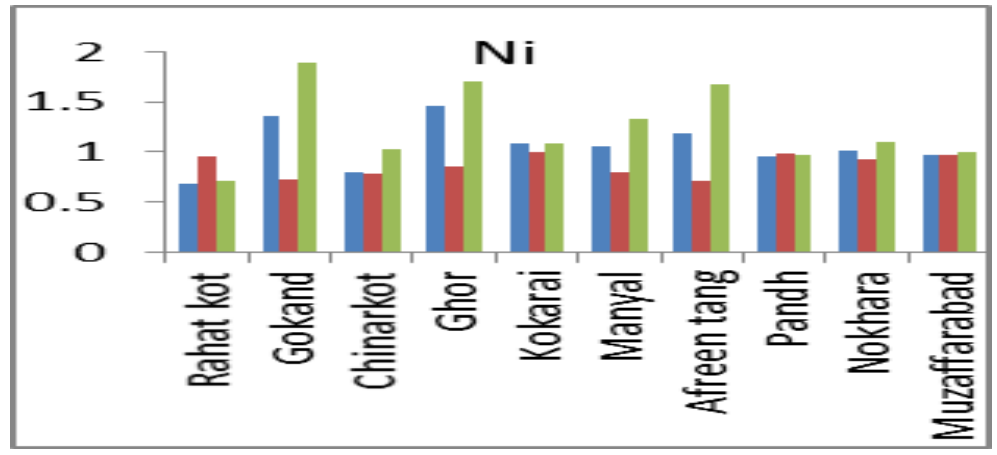

Fig. 2. Graphical representation of Ni Accumulation

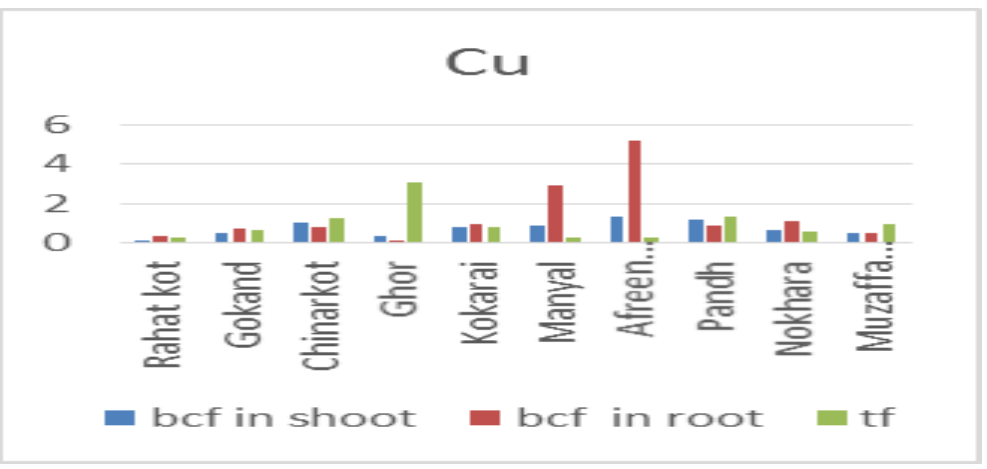

Fig. 3. Graphical representation of $\mathrm{Cu}$ Accumulation

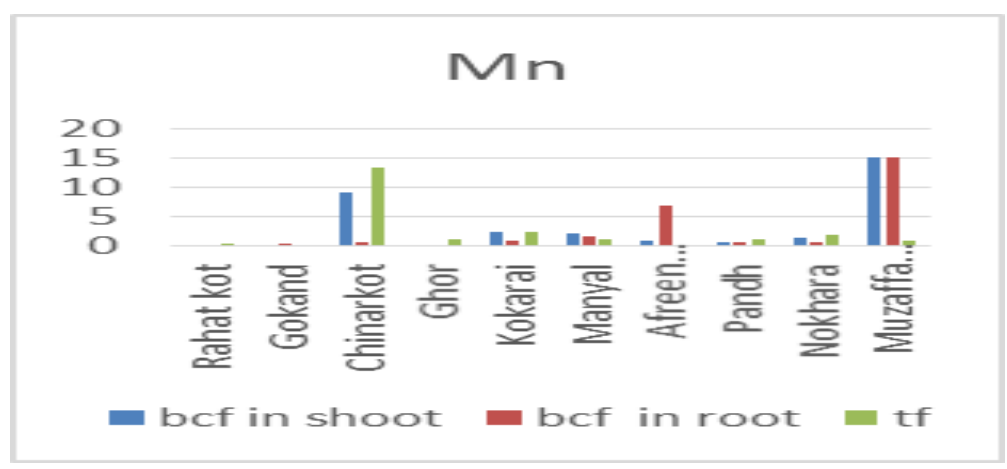

Fig. 4. Graphical representation of Mn Accumulation 


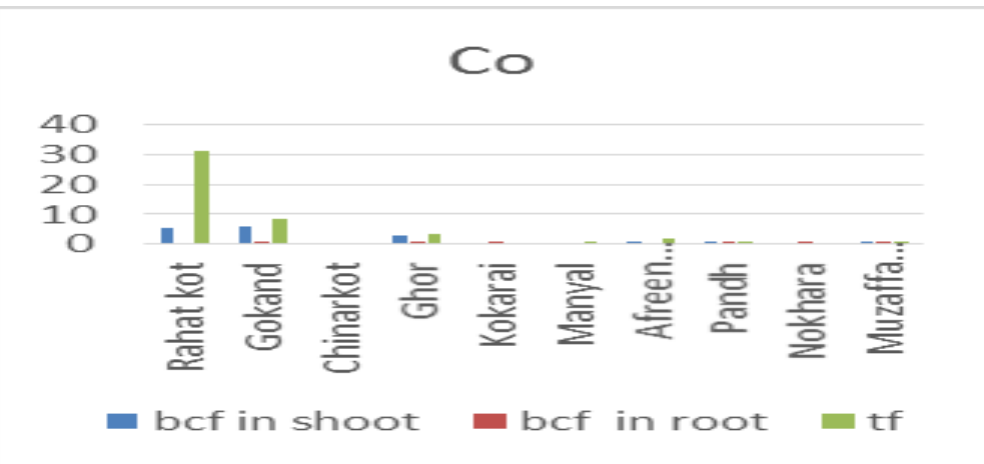

Fig. 5. Graphical representation of Co Accumulation

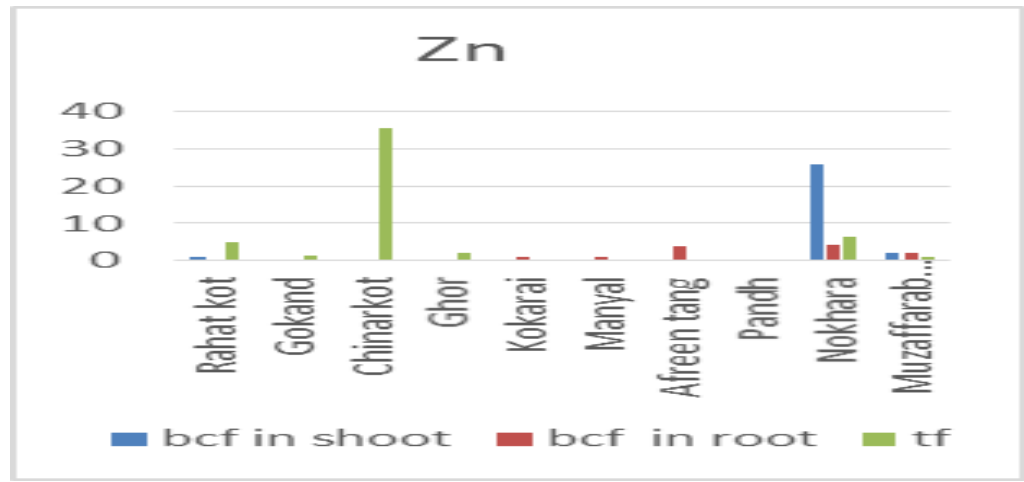

Fig. 6. Graphical representation of $\mathrm{Zn}$ Accumulation

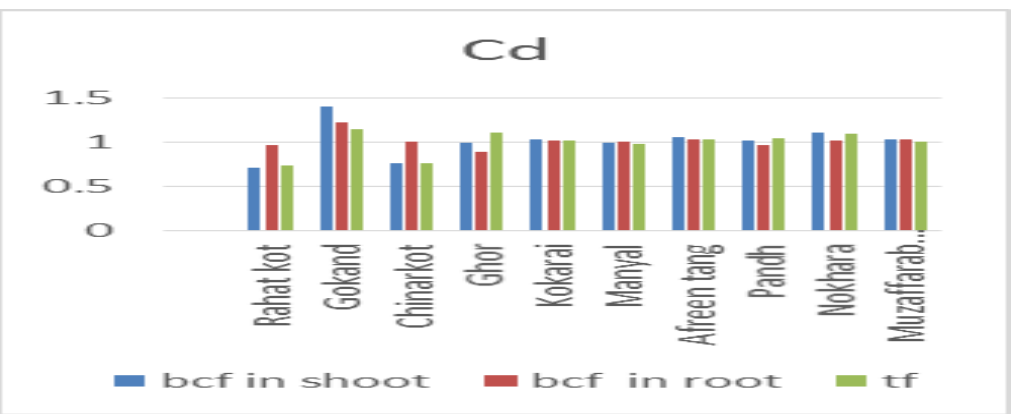

Fig. 7. Graphical representation of Cd Accumulation

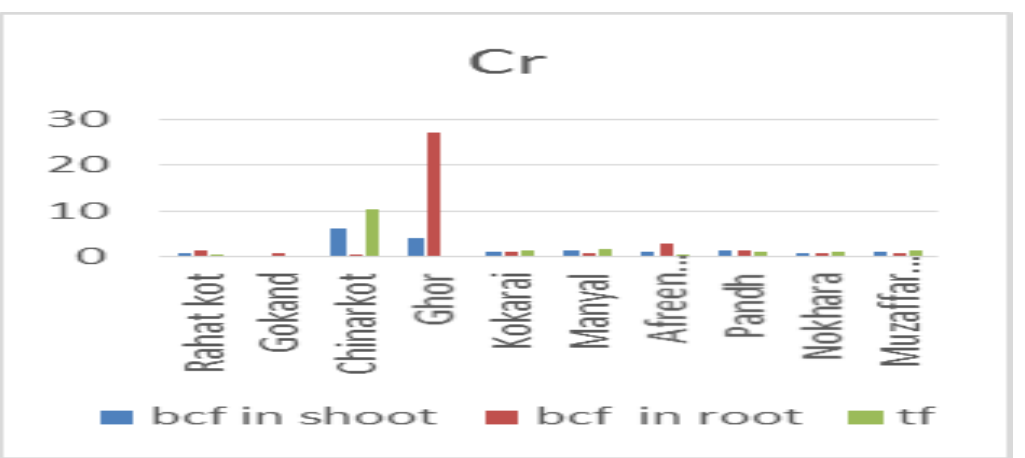

Fig. 8. Graphical representation of $\mathrm{Cr}$ Accumulation 


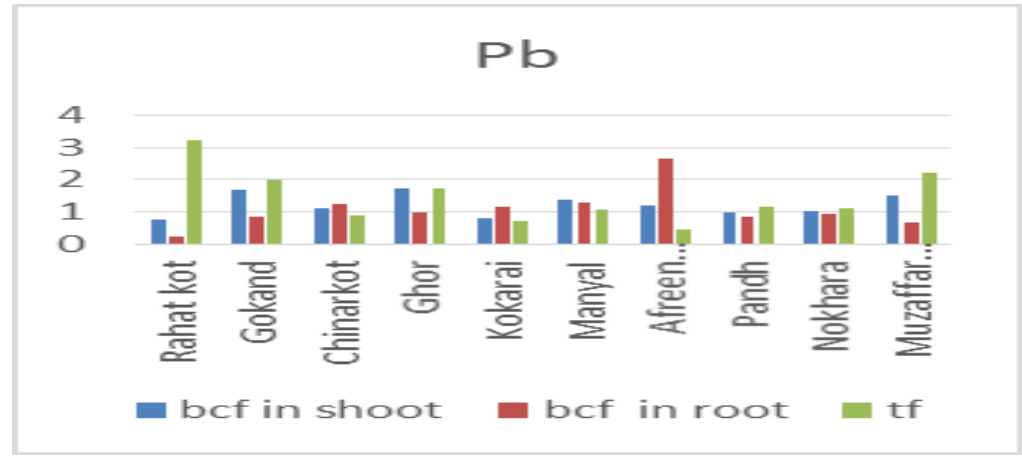

Fig. 9. Graphical representation of $\mathrm{Pb}$ Accumulation

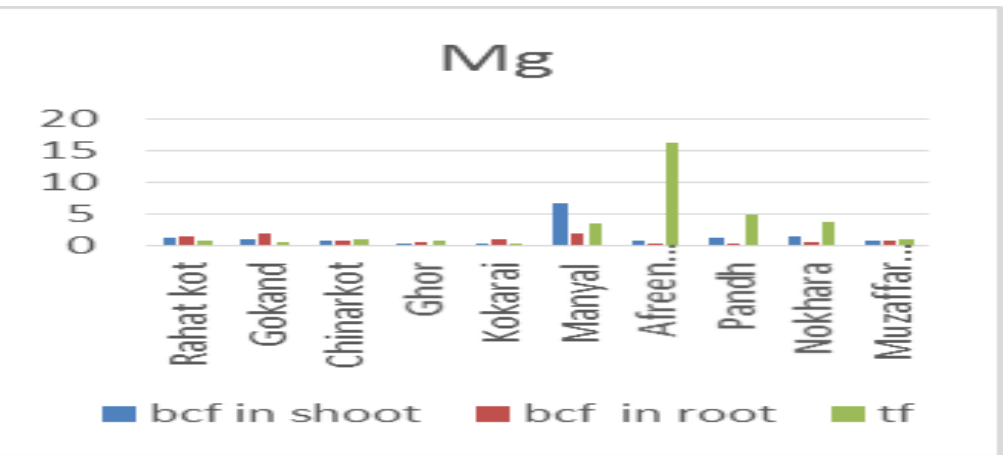

Fig. 10. Graphical representation of Mg Accumulation

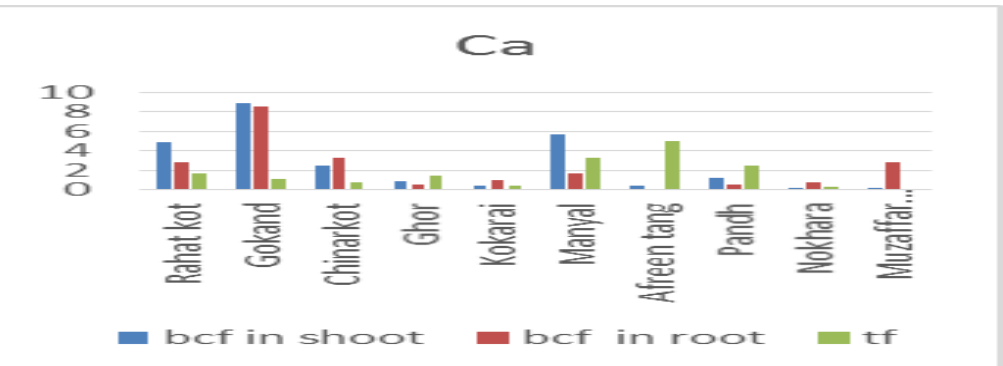

Fig. 11. Graphical representation of Ca Accumulation

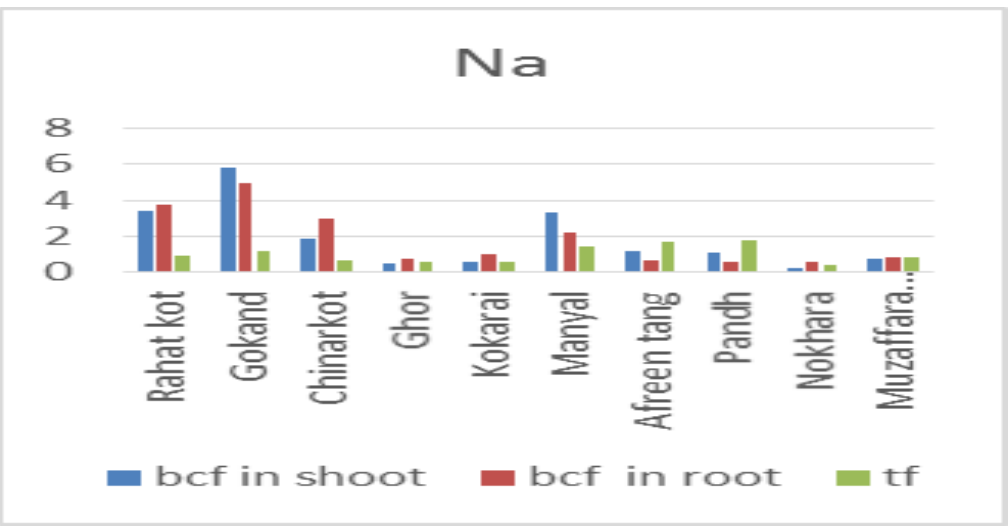

Fig. 12. Graphical representation of Na Accumulation 


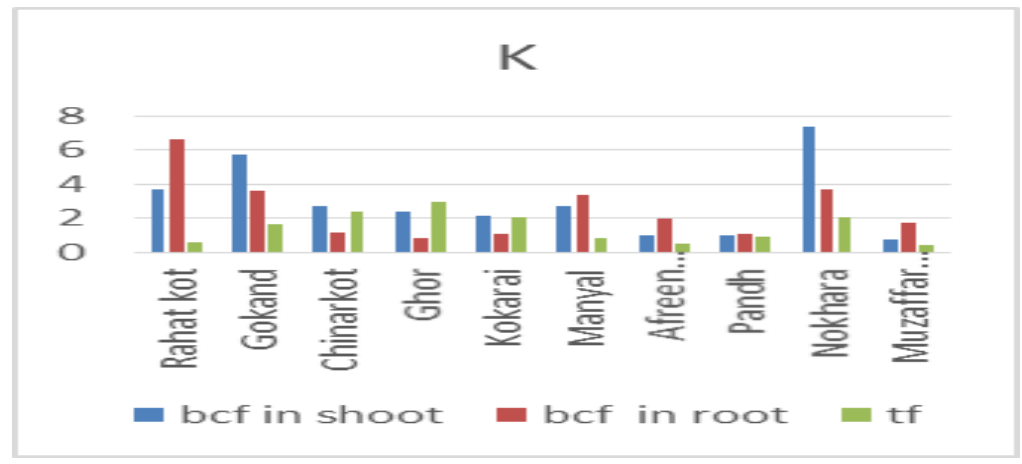

Fig. 13. Graphical representation of K Accumulation

\section{Conclusion}

Alnus nitida is economically and ecologically important Holarctic plant present in Western Himalayas of Pakistan. The results of the present research work shows that Himalayan Alder is a multipurpose plant providing ecosystem services to the community. The plant is having best capability of bioaccumulation for heavy metal in hilly areas, which will help in filtering of drinkable water from heavy metals and will enhance the quality of water. Himalayan Alder conservation and afforestation is necessary for future generation otherwise the recent speed of deforestation will led it to extinction from western Himalayan regions of Pakistan.

\section{Author's contributions}

Manuscript written: ZU Haq \& SM Khan, Data Collection: Abdullah, Lab work: A Ullah, References arrangement: A Razzaq \& F Manan, Data analysis: S Kamran, Revised paper: Z Ahmad, Paper format arrangement: $S$ Rasheed.

\section{References}

1. Dickinson NM, Turner AP, Watmough SA \& Leep NW (1992). Acclimation of trees to pollution stress: cellular metal tolerance traits. Annals of Bot 70(6): 569-572.

2. Din BU, Javed MT, Rafique M, Kamran MA, Mehmood S, Khan M \& Chaudhary HJ (2019). Assisted phytoremediation of chromium spiked soils by Sesbania
Sesban in association with Bacillus xiamenensis PM14: A biochemical analysis. Plant Physiol and Biochem.

3. Longoni L, Papini M, Brambilla D, Arosio D and Zanzi L (2016). The role of the spatial scale and data accuracy on deep-seated gravitational slope deformation modeling: The Ronco landslide, Italy. Geomorphol 253:74-82.

4. Rafique M, Chaudhary HJ, Ahmed IA, Bykova A, \& Ortas I (2019). Biochar Engineered to enhance the potential performance of soil in the Mediterranean region of Turkey. Arabian $J$ of Geosci 12(12): 391.

5. Rascio N \& Navari-Izzo F (2011). Heavy metal hyperaccumulating plants: how and why do they do it? And what makes them so interesting. Plant Sci 180(2):169-181.

6. Khan SM, Page SE, Ahmad H \& Harper DM (2013). Sustainable utilization and conservation of plant biodiversity in montane ecosystems: the western Himalayas as a case study. Annals of Bot 112(3): 479-501.

7. Mehmood T, Chaudhry M, Tufail M \& Irfan N (2009). Heavy metal pollution from phosphate rock used for the production of fertilizer in Pakistan. Microchemical J 91(1): 94-99.

8. Haq ZU, Rashid A, Khan SM, Razzaq A, Al-Yahyai, R A, Kamran S, \& Rehman 
A (2019). In vitro and in vivo propagation of Monotheca buxifolia (Falc.) A. DC. An economical medicinal plant. Acta Ecologica Sinica.

9. Malik Z, Hussain F \& Malik, N (2007). Life form and leaf size spectra of plant communities Harbouring Ganga Chotti and Bedori Hills during 1999-2000. Inter J Agric Biol 9(6): 833-838.

10. Silva JNM, de Carvalho Jd, do Ca LopesJ, De Almeida B, Costa D, de Oliveira Ld, Skovsgaard J (1995). Growth and yield of a tropical rain forest in the Brazilian Amazon 13 years after logging. Forest Ecol and Manag 71(3): 267-274.

11. Silva JNM, de Carvalho Jd, do Ca Lopes J, De Almeida B, Costa D, de Oliveira Ld \& Skovsgaard J (1995). Growth and yield of a tropical rain forest in the Brazilian Amazon 13 years after logging. Forest Ecol and Manag 71(3): 267-274.

12. Furlow JJ (1990). The genera of Betulaceae in the southeastern United States. J of the Arnold Arboretum, 71(1): 1-67.

13. Benson DR \& Silvester W (1993). Biology of Frankia strains, actinomycete symbionts of actinorhizal plants. Microbiol Rev 57(2): 293-319.

14. Yu S, Wang C, Ren K \& Lou W (2010). Achieving secure, scalable, and finegrained data access control in cloud computing. Paper presented at the Infocom, 2010 proceedings IEEE.

15. Khan N \& Asghari B (2016). Role of Plant growth promoting rhizobacteria and Ag-nano particles in the bioremediation of heavy metals and maize growth under municipal waste water irrigation, international journal of phytoremediation.

16. Furlow JJ (1979). The systematics of the American species of Alnus (Betulaceae). Rhodora 81(825): 1-121.

17. Li CY, Jiang LY, Chen WY, Li K, Sheng HQ, Ni Y, Shi QX (2009). CFTR is essential for sperm fertilizing capacity and is correlated with sperm quality in humans. Human Reproduc 25(2): 317327.

18. Li DZ \& Pritchard HW (2009). The science and economics of ex situ plant conservation. Trends in Plant Sci 14(11): 614-621.

19. Lin SM, Liu CY, Wang CH, Lin HC, Huang CD, Huang PY \& Kuo HP (2004). The impact of delirium on the survival of mechanically ventilated patients. Critical Care Med 32(11): 2254-2259.

20. Turner AP \& Dickinson NM (1993). Survival of Acer pseudoplatanus L (sycamore) seedlings on metalliferous soils. New Phytologist 123(3): 509-521.

21. Shin MN, Shim J, You Y, Myung H, Bang KS, Cho M \& Oh BT (2012). Characterization of lead resistant endophytic Bacillus sp. MN3-4 and its potential for promoting lead accumulation in metal hyperaccumulator Alnus firma. $J$ of Hazardous Materials 199: 314-320.

22. Gunatilake SK (2015). Methods of removing heavy metals from industrial wastewater. Methods 1(1): 14. 